\title{
透かし印章を用いた電子文書のテキスト 復元
}

\author{
Recovering scheme for Electronic Documents by Watermark \\ to Signature Seal.
}

岩切宗利 ${ }^{\dagger}$, 正会員 松井甲子雄 ${ }^{\dagger}$

Munetoshi Iwakiri ${ }^{\dagger}$ and Kineo Matsui ${ }^{\dagger}$

あらまし ディジタル化したテキスト文書の一部が不正に改ざんされても，その内容をオリジナルの状態に復元でき る手法を提案する，それは，テキストが埋め込まれた印章画像を電子文書に貼付し，記述内容が不正な改ざんを受けた 場合に，透かしデータを抽出して原本を復元するものである.

キーワード: 電子透かし, 浪度パターン法, テキスト復元, 改ざん検出, 電子印章

\section{1. まえがき}

情報のディジタル化は, その保存性や可搬性の高さか ら広い分野への応用が期待されている. 特に文書のディ ジタル化によるオンライン取引は，大幅なコストダウン と情報の速達およびその共有に慗がるものとして，早期 の実現が期待されている. しかし, ディジタルデータは, 一部を不正に改ざんされてもその痕跡が残りにくい特徴 を持つため，暗号技術 ${ }^{1)}$ によるセキュリティ対策が不可 欠であった．暗号化はデータの保全性を高める上で有効 かつ強力なものであるが, 復号された後のデー夕の安全 性を保証できないうえに，記述内容の自由な閲覧を制限 する．また，署名方式によれば文書デー夕から生成され るハッシュ值を用いて改ざん箇所を特定できるが，その 復元はできない. そこで, 文書データをグリフコード 2) やバーコード 3) として余白に貼付し, 改ざん箇所の復元 に役立てることも考えられる。しかし，コンテンツとし て無意味なコードパターンを添付するのは望ましくない. 本研究では, これらの問題解消策のひとつとして電子 透かし ${ }^{4)}$ の応用を検討した. その方法は, テキストデー 夕が埋め込まれた印章画像をディジタル文書に貼付し， 記述内容の改ざん検出および改ざん箇所の復元に役立て るものである.これによれば, 利用者は透かしの存在を 意識することなく電子文書を活用でき, もし改ざんの痕 跡が認められたならば, 印章部分からテキストを復元で きる.

\footnotetext{
2000 年 1 月 24 日受付, 2000 年 2 月 16 日採録

†防衛大学校 情報工学科

（广 239-8686 横須賀市走水 1-10-20, TEL 0468-41-3810）

† Department of Computer Science, National Defense Academy

(1-10-20 Hashirimizu, Yokosuka-shi, Kanagawa 239-8686, Japan)
}

\section{2. 埋込みの原理}

\section{1 濃度パターン法の原理}

濃度パターン法は, 人間の視覚的積分効果を巧みに利 用し, 高階調の多值画像を低階調で擬似的に表現する組 織的ディザの一種である ${ }^{5)}$. ここで, ディザの各セルの 大きさを $d \times d$ とし, 各画素が $L_{p}$ 階調を表現できると する. このときの擬似階調数 $L_{s}$ は

$$
L_{s}=\left(L_{p}-1\right) \cdot d^{2}+1
$$

となる.ここで， $L_{p}=2$ のとき表現解像度が高く視覚 的積分効果を得られるならば, その濃度值はセル内の画 素数で定まる. 例えば $d=2$ の濃度パターンは図 1 のよ うになる. $s_{q}=0,4$ を除く各量子化值には少くとも 4 種 類のパターン選択肢があり，その自由度を利用し，デー 夕 $t$ を $2 \mathrm{bit}$ まで埋め込むことができる.一般に， $L_{o}$ 階 調の濃淡画像 $S$ のある 1 画素を $s$ としたとき, その $L_{s}$ 階調への量子化は

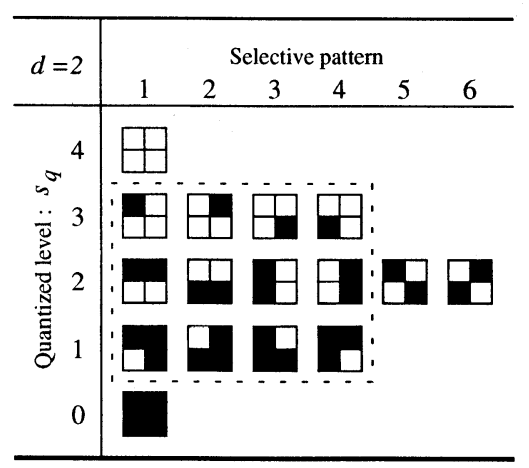

図 1 埋込みの原理 Embedding rule. 


$$
s_{q}=\left\lfloor s \cdot \frac{L_{s}}{L_{o}}\right\rfloor
$$

で求まる.このとき出力セルに埋め込めるビット長 $b_{l}$ は, セルサイズ $d$ と量子化值 $s_{q}$ を用いて

$$
b_{l}=\left\lfloor\log _{2}\left(d^{2} \mathrm{C}_{s_{q}}\right)\right\rfloor
$$

のように定まる. ただし,$d^{2}>s_{q}$ である.

\section{2 濃度パターンの決定法}

テキスト $T$ から抽出した $b_{l}$ ビットのデー夕 $t$ により, セルの画素配列を一意に定める原理を示す ${ }^{6)}$. まず, $d \times d$ のセル要素を 1 次元に再排列し $D(j), j=0,1, \cdots, d^{2}-1$ と表現する.このとき, セルパターンの総数は, $d^{2}$ 個 のセルから $s_{q}$ 個を選ぶ組合せ ${ }_{d^{2}} \mathrm{C}_{s_{q}}$ に等しい.ここで $D(0)$ に着目してパターンの組合せを展開すると

$$
{ }_{d^{2}} \mathrm{C}_{s_{q}}={ }_{d^{2}-1} \mathrm{C}_{s_{q}-1}+{ }_{d^{2}-1} \mathrm{C}_{s_{q}}
$$

になる．この右辺第 1 項は $D(0)$ を “ 1 ”, 第 2 項は “ 0 ” としたパターンの種類数を示す. そこで, $t<_{d^{2}-1} \mathrm{C}_{s_{q}-1}$ ならば $D(0)=1$ として $s_{q}$ を $s_{q}-1$ に置き換える. 一方, そうでないならば $D(0)=0$ として $t$ から $d_{d^{2}-1} \mathrm{C}_{s_{q}-1}$ を

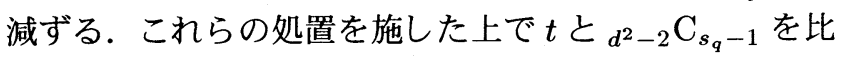
較し $D(1)$ を定める.これを再帰的に繰り返し $D(j)$ を 決定する. これは基数変換と同様の原理である.

\section{3. 印章の作成}

多値の印章画像 $S$ を準備する. 一方, テキスト $T$ およ びタイムスタンプ $P$ を暗号化し, その暗号データを $X$ とする. この $X$ から $b_{l}$ ビットのデータ $x$ を抽出し, 濃 度パターン画像 $S^{\prime}$ を作成する. この $S^{\prime}$ と $T$ を文書整形 ソフトで合成し印章付の文書データ $Y$ を作成する. この 際, 印章画像のセルパターンを圧縮等で損失してはなら ない.

\section{4. テキストの復元}

印章からテキストを復元するには, 各画素がビットパ ターンに対応しなければならない.しかし, 印章画像は 表示バランスを考慮してサイズを調整した後に貼付され る. したがって, データの復元時は, まず印章画像を画 素ブロックに分割しビットパターンに置き換える前処理 が必要である. たとえば $50 \times 50$ ビットの印章を $200 \mathrm{dpi}$ の紙面に 1 インチ角のサイズで貼付すると, 各ビット值 が $4 \times 4$ の画素ブロックで表現されるので, 抽出画像は $200 \times 200$ 画素となる. これをビットパターンへ変換す るには, 縦横のサイズを $1 / 4$ に縮小し 2 值化しなければ ならない。

まず，復元対象文書 $Y^{\prime}$ に含まれる印章画像データ $S^{\prime}$ の画素をセルサイズに縮小する.これを 2 值化して， 1 次元に再排列し $D(j), j=0,1, \cdots, d^{2}-1$ とする. また, 量子化值を
表 1 印章への埋込み容量

Embedable capacity to seals.

\begin{tabular}{c|c|c}
\hline Name & Capacity(bits) & Size(pixel) \\
\hline INKAN & 26,026 & $50 \times 50$ \\
\hline SEAL & 55,484 & $100 \times 50$ \\
\hline
\end{tabular}

表 2 テキストデー夕量

Amount of text data for experiment.

\begin{tabular}{c|c}
\hline Name & Amount of data (bits) \\
\hline JTEXT & 5,944 \\
\hline ETEXT & 5,832 \\
\hline
\end{tabular}

$s_{q}=\sum_{j=0}^{d^{2}-1} D(j)$

により算出する. このとき $b_{l}$ ビットの埋込みデータは, 重係数

$$
w(j)={ }_{d^{2}-j-1} \mathrm{C}_{s_{q}-1-\sum_{i=0}^{j} D(j)}
$$

と $D(j)$ の論理否定 $\bar{D}(j)$ を用いて

$$
x^{\prime}=\sum_{j=0}^{d^{2}-1} \bar{D}(j) \cdot w(j)
$$

により算出できる. ただし,$s_{q}-1 \geqq \sum_{i=0}^{j} D(j)$ とす る.この処理を全画素ブロックに適用して得られた暗号 化データ $X$ を復号すれば, テキスト $T$ とタイムスタン プ $P$ を確認できる. ここで $T$ と $Y^{\prime}$ を比較し不整合箇所 を修正すれば, オリジナルの配布文書 $Y$ が復元できる. また, 印章から得られた暗号デー夕を復号できなければ, 文書が不正に処理されたと見なせる.

\section{5. 実 験 結 果}

実験に用いた印章画像をあらかじめ $0 \sim 15$ の 16 階調 に量子化し, 文字の形状をレベル 15(白色), 背景色レベ ル 5 (黒色)に変換した. この背景色レベルは量子化濃度 值 $s_{q}=10$ に相当する. この印章に埋込み可能なビット 容量を表 1 に示した。一方, 実験用テキストのデー夕量 は表 2 である．表 1 と表 2 の関係から，テキストデー夕 を複数回反復して印章画像に埋め込めることがわかる.

まず, JTEXT と ETEXT の一部にタイムスタンプと して処理時刻を添付し暗号化した.これらのテキスト データをセルサイズ $4 \times 4$ として, INKAN および SEAL へ埋め込み, 各印章にはテキスト抽出を容易にするため

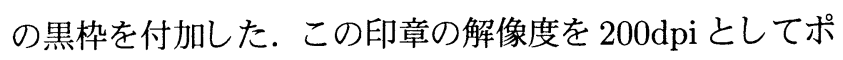
ストスクリプト言語による文書整形を施した配布文書は 図 2 のようになる. 図 2 から印章画像を抽出しテキスト を再現すると図 3 が得られた.この結果と図 2 を比較す ることで, この文書は改ざんされていないと判断できる.

\section{6. むすび}

本研究では, 電子文書の改ざんや偽造を防止する一手 
ITU-T 勧告 H.263 は $64 \mathrm{Kbps}$ 以下の低レート符号化に適し、テレビ電話に も利用可能なレベルの動画像を対象とする符号化手順である. 本報告では, この H.263 システムにおいて可変表示できる電子透かしを埋め込む方法を提 案する. まず, カラー画像の入力フレームを $\mathrm{YCbCr}$ 成分に分解し, その $\mathrm{Y}$ 成分に著作権を表すロゴマークを埋め込む. 提案する手法はこのロゴマーク を数フレーム間では可視状態で表示し，他の数フレーム間では不可視状態と して周期的に綝返し表示する方法である.この方法によれば, 著作権の所在 を積極的に明示できる利点がある，一方，可視表示されたロゴマークはユー ザの要請によりいつでも不可視化することが可能である. この不可視化ロコ マークは既存の多くの見えない透かしと同じように作用するため，著作権管 理上のトラブル解消に寄与することができる.

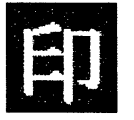

(a)JTEXT with INKAN.

ITU-T Recommendation H.263 system functions as $64 \mathrm{Kbit} / \mathrm{s}$ or less video encoder and is available for low bitrate communication such as video telephone. In this paper, we propose how to embed a variable-displaying watermark into $\mathrm{H} .263$ system. We transform input frames of color image in $\mathrm{YCbCr}$ format and embed a binary logomark into luminance $\mathrm{Y}$ for copyright protection. In our scheme the logomark is displayed repeatedly in visible state on several frames and in invisible state on others. By using this method, the author can show his copyright positively onto the video sequence and may change the displayed mark to invisible one without losing the watermark subject to the request of authorized users.

\section{seal}

(b)ETEXT with SEAL.

図 2 テキストと印章の合成文書 Seals and built-in documents.

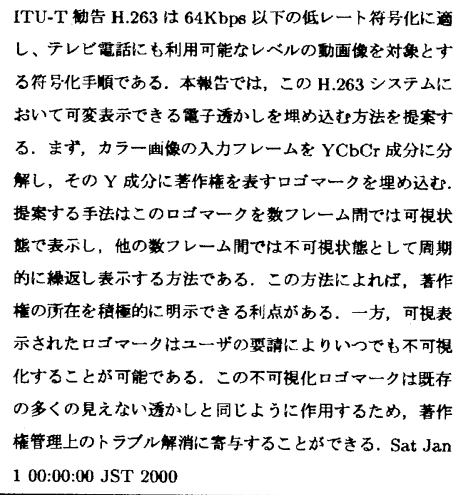

(a) Japanese text.

ITU-T Recommendation H.263 system functions as 64 $\mathrm{Kbit} / \mathrm{s}$ or less video encoder and is available for low bitrate communication such as video telephone. In this paper, we propose how to embed a variable-displaying watermark into $\mathrm{H} .263$ system. We transform input frames of color image in $\mathrm{YCbCr}$ format and embed a binary logomark into luminance $Y$ for copyright protection. In our scheme the logomark is displayed repeatedly in visible state on several frames and in invisible state on others. By using this method, the anthor can show his copyright positively onto the video sequence and may change the displayed mark to invisible one without losing the watermark subject to the request of authorized users. Sat Jan 1 00:00:00 JST 2000

(b) English text.

図 3 復号テキスト

Decoded texts.
法を提案した。 それは濃度パターン法を用いて, 電子印 章自体にテキストデータの改ざん検出および復元機能を 持たせるものである. 本手法によれば，電子文書の記述 内容が不正に改ざんされても印章からテキストを復元で きる.さらに図 2 の出力文書をコピー機で複製すると印 章部分の微細な画素が崩れるので, 原本かコピーかの判 定も可能となる利点がある. この研究では, 本手法の有 用性を実験的に確認した。実用化に際しては，暗号化の 手法やテキスト復号時の誤り訂正に関してさらなる検討 が必要であろう.

\section{〔文献〕}

1) D.R.Stinson : “CRYPTOGRAPHY”, CRC(1995) (櫻井幸一監訳 : “暗号理論の基礎”，共立出版 (1996))

2) D.L.Hecht: "Embedded Data Glyph Technology for Hardcopy Digitaldocuments", Proc. SPIE. 2171, Color Hardcopy and Graphic Arts III, pp.341-352(1994)

3）小塚洋司：“バーコードの秘密”，裳華房 (1996)

4）松井甲子雄：“電子透かしの基䃈”，森北出版（1998）

5）藤村是明：“ドット式表示装置による浱淡図形表示の方法”, 情報処理, 15, 7, pp.503-509(1974)

6）中村康弘，松井甲子雄：“嶩度パターン法を用いた濃淡画像とテキストデー 夕の合成符号化法”，信学論，70-B, 12, pp.1475-1481(1987)

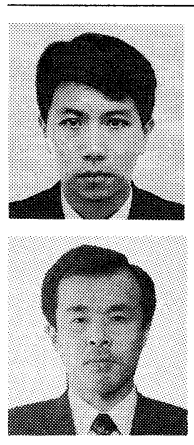

岩切等紫利 1993 年, 防衙大学校情報工学科卒業。 1998 年, 同大学校理工学研究科情報数理専攻修了. 1999 年, 防街大学校情報工学科助手. マルチメティア符号化，情 報セキュリティ，電子透かしに関する研究に従事.

淞并甲㭌雄 1961 年, 防衛大学校電気工学科卒業, 1965 年, 九州大学大学院工学研究科電子専攻修了, 1981 年, 防街大学校電気工学科教授. 1989 年, 同大学校情報 工学科教授. 暗号学, 情報セキュリティ, 電子透かし, 音 声・画像テー夕の符号化に関する研究に従事. 工学博士. 正 会員. 